\title{
A Broad View of Macroeconomic Stability
}

\author{
José Antonio Ocampo*
}

\begin{abstract}
This paper recommends a broad concept of macroeconomic stability, whereby "sound macroeconomic frameworks" include not only price stability and sound fiscal policies, but also a well-functioning real economy, sustainable debt ratios and healthy public and private sector balance sheets. These multiple dimensions imply using multiple policy instruments. The paper elaborates a framework for developing countries that involves active use of countercyclical macroeconomic policies (exchange rate, monetary and fiscal), together with capital management techniques (capital account regulations and prudential rules incorporating macroeconomic dimensions). It also explores the role of international financial institutions in facilitating developing countries' use of countercyclical macroeconomic policies.
\end{abstract}

The concept of macroeconomic stability has undergone considerable changes in the economic discourse over the past decades. During the post-war years dominated by Keynesian thinking, macroeconomic stability basically meant a mix of external and internal balance, which in turn implied, in the second case, full employment and stable economic growth, accompanied by low inflation. Over time, fiscal balance and price stability moved to centre stage, supplanting the Keynesian emphasis on real economic activity. This policy shift led to the downplaying and even, in the most radical views, the complete suppression of the countercyclical role of macroeconomic policy. Although this shift recognized that high inflation and unsustainable fiscal deficits have costs, and that "fine tuning" of macroeconomic policies to smooth out the business cycle has limits, it also led to an underestimation of both the costs of real macroeconomic instability and the effectiveness of Keynesian aggregate demand management.

This shift was particularly sharp in the developing world, where capital account and domestic financial liberalization exposed developing countries to the highly procyclical financial swings characteristic of assets that are perceived by financial markets as risky, and thus subject to sharp changes in the "appetite for risk". In the words of Stiglitz (2002), such exposure replaced Keynesian automatic stabilizers with automatic destabilizers. Thus, contrary to the view that financial markets would play a disciplining role, dependence on financial swings actually encouraged the adoption of pro-cyclical monetary and fiscal policies that increased both real macroeconomic instability and the accumulation of risky balance sheets during periods of financial euphoria which led, in several cases, to financial meltdowns.

There is now overwhelming evidence that pro-cyclical financial markets and procyclical macroeconomic policies have not encouraged growth; they have in fact increased growth volatility in developing countries that have integrated to a larger extent in

\footnotetext{
* This is a revised version of a paper previously presented at the Seminar "From the Washington Consensus Towards a New Global Governance" at the Universal Forum for Cultures, Barcelona, 24-25 September 2004. I thank participants in the Forum and Stephany Griffith-Jones, Maria Angela Parra, Lance Taylor and Camilo Tovar for their comments on the prior version of this paper.
} 
international financial markets (Prasad, et al., 2003). This has generated a renewed but still incomplete interest in the role that countercyclical macroeconomic policies can play in smoothing out - that is, in reducing the intensity of - business cycles in the developing world. At the same time, since the Asian crisis, recognition has grown that liberalized capital accounts and financial markets tend to generate excessively risky private sector balance sheets, and that an excessive reliance on short-term external financing enhances the risks of currency crises. Preventive (prudential) macroeconomic and financial policies, which aim to avoid the accumulation of unsustainable public and private sector debts and balance sheets during periods of financial euphoria, have thus become part of the standard recipe since the Asian crisis. This represents, however, only a partial return to a countercyclical macroeconomic framework, for no equally strong consensus has yet emerged on the role of expansionary policies in facilitating recovery from crises.

Thus, the menu of macroeconomic policies has broadened in recent years. We have only come part of the way, however, to the full recognition that macroeconomic stability involves multiple dimensions, including not only price stability and sound fiscal policies, but also a well-functioning real economy, sustainable debt ratios, and healthy domestic financial and non-financial private sector balance sheets. A well-functioning real economy requires, in turn, smoother business cycles, moderate long-term interest rates and competitive exchange rates, all of which may be considered intermediate goals of the ultimate Keynesian objective: full employment. Such a broad view of macroeconomic stability should recognize, in any case, that there is no simple correlation between its various dimensions and, thus, that multiple objectives and significant tradeoffs are intrinsic to the design of "sound" macroeconomic frameworks.

This view should lead to the recognition of the role played by two sets of policy packages, whose relative importance will vary depending on the structural characteristics, the macroeconomic policy tradition and the institutional capacity of each country. The first involves a mix of countercyclical fiscal and monetary policies with appropriate (and, as we will argue, generally intermediate) exchange rate regimes. The second includes a set of capital management techniques designed to reduce the unsustainable accumulation of public and private-sector risks in the face of pro-cyclical access to international capital markets.

To encourage economic growth, such interventions through the business cycle should lead to sound fiscal systems that provide the necessary resources for the public sector to do its job, a competitive exchange rate and moderate long-term real interest rates. These conditions, together with deep financial markets that provide suitably priced investment finance in the domestic currency with sufficiently long maturities, are the best contribution that macroeconomics can make to growth.

This paper calls for a broad view of macroeconomic stability and for active countercyclical macroeconomic policies supported by the equally active use of capital management techniques. It is divided into four sections. The first section identifies some "stylized facts" about financial and real macroeconomic instability in developing countries. The subsequent two sections each analyze one of the afore-mentioned policy packages. The last takes a brief look at the implications of this framework for international cooperation. 


\section{Some stylized facts}

\section{The characteristics and costs of capital account volatility}

Trade - including terms of trade - fluctuations continue to play a major role in the determination of business cycles in developing countries, particularly in commoditydependent economies. Domestic factors, including political and climatic variables, also continue to play a role. Nonetheless, the distinguishing feature of developing country business cycles since the 1970s has been the leading role played by capital account fluctuations, particularly in those economies with access to international private capital markets (the "emerging" economies).

These new sources of vulnerability are associated with the flow and balance-sheet effects of capital-account fluctuations on the behaviour of domestic financial and nonfinancial agents. Rather than the price and wage rigidities emphasized by traditional macroeconomic models, financial variables - such as capital-account cycles, their domestic financial multipliers and their reflection in asset prices-have thus become the major determinant of growth volatility (Easterly, et al., 2001). Furthermore, whereas some of the effects of financial instability are transmitted through public-sector accounts (as the first generation of crisis models tended to emphasize), the dominant feature of the "new generation" of business cycles in developing countries is the sharp fluctuation in private spending and balance sheets. A major implication of this is that "twin" external and domestic financial crises have become more frequent since the breakdown of Bretton Woods exchange rate arrangements in the early 1970s (IMF, 1998; Bordo, et al., 2001).

Boom-bust capital-account cycles in developing countries are characterized by the twin phenomena of volatility and contagion. The first is associated with significant changes in risk evaluation of what international market agents consider to be risky assets, which involve the alternation of periods of "appetite for risk" (or, more properly, underestimation of risks) with those in which there is a "flight to quality" (risk aversion). The second implies that, due to the costs and asymmetries in information, developing countries (or groups of them) are pooled together in risk categories viewed by market agents as being strongly correlated. Beyond any objective criteria that may underlie such views, this practice turns such correlations into self-fulfilling prophecies. Countries are then pulled in the same direction by the herding behaviour of investors, generating both a contagion of optimism and a contagion of pessimism. Furthermore, market-sensitive risk management practices as well as other features of financial market operations (such as benchmarking and evaluation of managers against competitors) tend to increase this herding behaviour (Persaud, 2000).

As a result of these factors, developing countries were pulled together into the financial boom that started in the early 1990s (Calvo, et al., 1993), but they have also been subject to a clustering of "sudden stops" in external financing since the Asian crisis (Calvo and Talvi, 2004), in both cases with some independence from the "fundamental" macroeconomic factors. In turn, financial market evaluations are subject to pro-cyclical patterns - as reflected, for example, in the highly pro-cyclical pattern of credit ratings (Reisen, 2003). They are also subject to the inconsistent judgment of individual economies over time, which may lead to some "success" stories being reclassified as financial pariahs (e.g. Argentina) and pariahs reclassified as "investment grade" (e.g. Russia). Interestingly, due to herding behaviour, countries viewed by markets as "success" stories are almost inevitably drawn into the boom, inducing sizeable private- 
sector deficits (Ffrench-Davis, 2001; Marfán, 2005) that may subject them to the endogenous unstable dynamics which have been analyzed by Minsky (1982) and Taylor (1998), among others.

Volatility is reflected in the pro-cyclical pattern of spreads (narrowing during booms, widening during crises), but also in variations in the availability of financing (the presence or absence of credit rationing) and in maturities (reduced availability of longterm financing during crises, or the use of options that have a similar effect). The feedback between increases in spreads (country risk premia), debt accumulation and short-term macroeconomic expectations during crises can be highly destabilizing, particularly in the presence of high debt/export ratios (Frenkel, 2005). Different types of capital flows are subject to different volatility patterns. In particular, the higher volatility of short-term capital indicates that reliance on such financing is highly risky (Rodrik and Velasco, 2000), whereas the smaller volatility of FDI vis-à-vis all forms of financial flows is considered a source of strength.

Capital-account cycles involve short-term movements, such as the very intense movements of spreads and the frequency of interruption (rationing) of financing. These phenomena were observed during the Asian and, particularly, the Russian crises. Perhaps more importantly, however, they also involve medium-term fluctuations, as the experience of the past three decades indicates. Indeed, during these decades, the developing world has experienced two such medium-term cycles that left strong imprints in the growth rates of many countries: a boom of external financing (mostly in the form of syndicated bank loans) in the 1970s, followed by a debt crisis in a large part of the developing world in the 1980s; and a new boom in the 1990s (then mostly portfolio flows), followed by a sharp reduction in net flows since the Asian crisis.

There is widespread evidence that ample private sector financing encourages, and certainly rewards, pro-cyclical macroeconomic policies during booms. On the other hand, authorities are expected to behave in ways that generate "credibility" for financial markets during crises, which means that they are judged according to their capacity to adopt pro-cyclical austerity policies. This generates, in turn, economic and political economy pressures to also adopt pro-cyclical policies during booms. Financial and nonfinancial agents resist then the restrictions that authorities may impose on their ability to spend or lend, whereas authorities are only too happy to have some breathing space after a period of austerity. Thus, contrary to the notion that financial markets would have a disciplining effect, unstable external financing has, in a strong sense, distorted the incentives that economic agents and authorities face throughout the business cycle, inducing pro-cyclical behaviour from both economic agents and macroeconomic policies.

The costs of financial volatility in terms of economic growth are high. Volatility leads to a high average rate of underutilization of production capacity that reduces the productivity of capital. In turn, the uncertainty associated with variability in growth rates has adverse effects on capital accumulation (Loayza, et al., 2003). More importantly, in the presence of increasing returns, strong recessions generate significant losses of resources that may have cumulative effects (Easterly, 2001, chapter 10). In the most favourable case, this will be reflected in a once-and-for-all loss in GDP (as in the experience of Korea during the Asian crisis); in the most adverse case, it will lead to a displacement in the long-term growth trajectory (as in most Latin American countries in the 1980s, or Indonesia during the Asian crisis). 


\section{The underlying financial and macroeconomic asymmetries}

The dynamics of boom-bust cycles are deeply rooted in the operation of financial markets, but also in some basic asymmetries of the world economy, which are largely (though not exclusively) of a centre-periphery character (Ocampo, 2003b; Ocampo and Martin, 2003). In the financial area, these asymmetries are reflected in three basic facts:

(a) the incapacity of most countries to issue liabilities in their own currencies, a phenomenon that has become known as "original sin" (Eichengreen, et al., 2003; Hausman and Panizza, 2003); (b) differences in the degree of domestic financial and capital market development, which lead to an under-supply of long-term financial instruments; and (c) the small size of developing countries' domestic financial markets vis-à-vis the magnitude of the speculative pressures they may face (Council on Foreign Relations, 2000). Taking the first two of these phenomena together, this implies that domestic financial markets in the developing world are significantly more "incomplete" than those in the industrial world, and thus that some financial intermediation must necessarily be conducted through international markets. As a result, developing countries are plagued by variable mixes of currency and maturity mismatches in the balance sheets of their economic agents. This also implies that integration into international financial markets is an integration between unequal partners (ECLAC, 2000, ch. 8).

Financial asymmetries are reflected, in turn, in macroeconomic asymmetries, particularly in the capacity to undertake countercyclical macroeconomic policies. Industrialized countries, whose currencies are the international currencies, have larger degrees of freedom to undertake countercyclical macroeconomic policies and to induce a stabilizing response from markets. In contrast, as we have seen, developing countries have more limited degrees of freedom to do so, and face pro-cyclical pressures from financial markets (Kamisky, et al., 2004). In this sense, developing countries are both "business-cycle takers" and "policy takers" (Ocampo, 2002).

The risks associated with financial instability can be partly corrected by domestic policy actions. Indeed, this paper addresses ways of dealing with such vulnerabilities. Such actions, however, are not costless because "self-insurance" is costly. Furthermore, some of the policy actions that emerging economies can adopt to manage risks merely shift those risks, rather than correct them. For example, larger short-term capital flows can be counterbalanced by a simultaneous accumulation of international reserves, but this route implies a loss equivalent to the spread between lending and borrowing interest rates on the accumulated reserves. Also, the risks faced by the domestic financial sector can be counterbalanced by more strict prudential regulations of domestic financial activities than international (Basle) standards, but this raises the cost of financial intermediation and may restrict the development of new financial services. The move to a currency board regime or dollar/euro-ization can reduce or eliminate currency risks, but it may also make economic activity more volatile, given the restrictions placed on the adoption of countercyclical policies. There is, therefore, a very profound sense in which the financial and macroeconomic asymmetries that affect developing countries are inescapable. In this context, the search for shortcuts and "silver bullets" does not eliminate the difficult tradeoffs that such asymmetries generate, and it may actually increase the costs incurred in the absence of a broad framework for macroeconomic stability. 


\section{Countercyclical macroeconomic policy \\ The exchange rate regime and the scope for monetary autonomy}

The traditional instruments of trade and balance of payments management used by developing countries throughout most of the post-war period became severely criticized as a source of inefficiency and rent seeking; in recent years, therefore, they have been weakened or dismantled altogether. Interestingly, the countercyclical role that they played in economies where the business cycles are largely of an external origin has been generally overlooked. Thus, protection and export subsidies were used to encourage trade restructuring during periods of adverse external shocks, while trade liberalization and reduction of export subsidies were used to reduce the expansionary effects of export booms. Capital controls and dual exchange rates were also used to manage pro-cyclical swings in capital flows. In practice, trade and capital account liberalization thus eliminated instruments that could be used to manage externally-generated business cycles.

This left the exchange rate as the major and, in many cases, the only instrument of balance of payments management. The exchange rate can play a countercyclical role by encouraging trade restructuring through the business cycle - in promoting exports and efficient import substitution during periods of foreign exchange scarcity, and the opposite during periods of abundance. As the literature on the contractionary effects of devaluation (expansionary effects of appreciation) indicates, however, the aggregate demand effects of exchange rate fluctuations may be pro-cyclical, at least in the short run (Díaz-Alejandro, 1988, chapter 1; Krugman and Taylor, 1978).

Furthermore, real exchange rate fluctuations are not without costs if tradable sectors face learning and other dynamic economies of scale. In particular, appreciation pressures during periods of foreign exchange abundance (an increase in commodity prices or capital flows) may have long-term de-industrialization effects, as indicated in the literature on the "Dutch disease" (Krugman, 1990, chapter 7; van Wijnbergen, 1984). Real exchange rate instability is also costly if entry into tradable sectors has fixed costs (fixed capital investments or fixed costs of building a clientele in foreign markets). In broader terms, in open developing economies, the real exchange rate is one of the crucial determinants of investment, growth and employment (Frenkel, 2004).

In any case, in a world of capital account volatility, trade effects are overshadowed by the wealth effects that exchange rate fluctuations have in economies with currency mismatches in their balance sheets (net external liabilities denominated in foreign currencies). The capital gains generated by appreciation during upswings help to fuel the private spending boom, whereas the capital losses generated by depreciation have the opposite effect during downturns. Furthermore, such gains induce additional net inflows (including net variations of flight capital) when there are expectations of exchange-rate appreciation, and the opposite effect if depreciation is expected, thus providing endogenous reinforcement to the capital-account cycle.

Countercyclical monetary and fiscal policies could, in principle, counteract the pro-cyclical effects that real exchange rate fluctuations are likely to have in developing countries. A crucial factor is the degree of monetary autonomy allowed by different exchange rate regimes. In this regard, it has long been accepted that fixed exchange rate regimes eliminate monetary autonomy whereas flexible exchange rates provide room for autonomous monetary policies. As we will see, this traditional view of flexible exchange 
rates is not entirely valid. Indeed, recent evidence indicates that the degree of exchange rate flexibility may not be as crucial a determinant of the ability to undertake countercyclical macroeconomic policies as traditionally thought (Kamisky, et al., 2004).

These considerations imply that, in today's open developing economies, the exchange rate regime is subject to conflicting and not easily reconcilable demands. These conflicts are exacerbated by capital account volatility, by the strong aggregate demand and supply effects of exchange rates on developing economies, and by the reduced degrees of freedom enjoyed by authorities in a world of limited policy instruments.

Although these contradictory demands can be expressed in different ways, they can usefully be defined as the tensions faced by exchange regimes between the demand for stability and the demand for flexibility (Ocampo, 2002). The demand for stability comes from trade, but also from domestic price stability and the need to avoid the procyclical wealth effects of exchange rate fluctuations. The demand for flexibility comes from the need to have some degrees of freedom to manage trade and capital account shocks. Authorities will thus tend to choose the exchange rate regime based on their preferences, but also on the relative benefits ("price") of flexibility vs. stability, which are determined by both the external environment and objective factors. Increased international instability (such as the breakdown of the dollar standard, a period of turmoil in world finance for "emerging" markets or a world recession) will increase the relative benefits of flexibility, whereas a period of tranquillity (as in the heyday of the Bretton Woods system, or a period of stable world economic growth) will increase the relative advantages of stability. In turn, while the benefits of flexibility will be higher for larger, less specialized economies, the benefits of nominal stability will be greater for smaller, more specialized economies.

Another way to characterize these conflicting demands begins, as does this paper, with the understanding that a broad framework for stability implies that economic authorities have, in fact, multiple objectives: low inflation, smoother business cycles, competitive real exchange rates, stable long-term interest rates and sound balance sheets. Achieving these multiple objectives requires some additional instruments, particularly countercyclical fiscal policies and prudential regulation and supervision of domestic financial systems (see below). Even if helped by these instruments, however, monetary authorities must not disregard their multiple objectives. Particularly, in addition to inflation targeting, they should not disregard the countercyclical role of monetary policy (output and employment targeting). Furthermore, to the extent that a stable, real exchange rate is a crucial determinant of growth and employment in open economies, an element of real exchange rate targeting is also an essential component of adequate macroeconomic management in developing countries (Frenkel, 2004). As indicated at the start of this section, this is particularly important when, as the result of liberalization, countries have given up their traditional trade policy instruments.

The call to choose polar exchange rate regimes does not capture the relevance of these conflicting demands. Rather, the defence of polar regimes is based on the argument that any attempt to manage the conflicting demands on exchange rate policy is futile and should thus be abandoned.

Hard pegs certainly introduce built-in institutional arrangements that provide for fiscal and monetary discipline and help to avoid currency mismatches and their procyclical effects (Calvo, 2001), but this choice is made at the cost of eliminating the output 
and real exchange rate objectives of monetary policy. Thus, under this type of regime, adjustment to overvaluation (if the economy gets "locked" into an overvalued exchange rate during the transition, or as a result of devaluations by major trade partners or of appreciation of the currency to which the exchange rate is pegged) is painful, and it may lead to low structural rates of growth mixed with strong business cycles. Nor is this regime speculation-proof, as evidenced by the experiences of Argentina in 1994-95 and 1998-2001, of Hong Kong in 1997 and, for that matter, of the gold standard in the periphery. More price flexibility could help, but it may nonetheless generate adjustment problems that are generally disregarded today. ${ }^{1}$ In particular, during the gold standard era, price flexibility tended to generate additional domestic financial risks during crises, due to the rapid increase in real debt burdens generated by deflation (which may be thought of as equivalent to very high real short-term interest rates). The gold standard also generated a strong short-term bias in bank lending, which was necessary to rapidly reduce nominal portfolios during periods of monetary contraction.

On the other hand, the volatility characteristic of freely floating exchange rate regimes increases the costs of trade transactions, thus reducing the benefits of international specialization. As developing countries are largely net importers of capital goods, exchange rate uncertainty also affects investment decisions. Its major benefit is thus the degree of monetary autonomy that it provides- that is, the ability to determine monetary policies on the basis of domestic factors, thus generating some room for countercyclical macroeconomic policies. But this benefit is unlikely to materialize fully, for two different reasons.

The first reason relates to the links between the exchange rate and the domestic price level in open economies. If monetary authorities follow strict inflation targeting rules, these effects are pro-cyclical. This is most visible in two widely used pro-cyclical policies: anchoring the price level to a fixed exchange rate during periods of foreign exchange abundance, and counterbalancing the inflationary effects of devaluation through contractionary monetary policies during periods of foreign exchange scarcity. Expressed in terms of the literature on open-economy inflation targeting, strict inflation targeting will generate more output volatility than flexible inflation targeting, which takes into account other objectives of monetary policy, particularly reducing the output gap (Svensson, 2000).

The second reason why inflation-targeting in a floating exchange rate regime is unlikely to result in countercyclical macroeconomic management relates to the effects of capital mobility. The key problem faced by the authorities during booms is that capital surges exert expansionary aggregate demand effects that are enhanced by the downward pressure on interest rates and/or exchange rate appreciation. Any attempt by policymakers to counteract these aggregate demand effects through contractionary monetary policies will be partly self-defeating, as the higher interest rates will induce additional capital inflows, and thus additional appreciation pressures. During crises, the reduction of capital inflows will have a direct effect on aggregate demand, which will be combined with a mix of devaluation and interest rate hikes. Any attempt to avoid the latter by using expansionary monetary policy will encourage a stronger devaluation. Thus, if authorities consider that the exchange rate fluctuations generated by boom-bust cycles are too strong to start with, they may be encouraged to use pro-cyclical monetary

\footnotetext{
${ }^{1}$ See, however, Easterly, et al. (2001) for a similar view to that exposed here.
} 
policy to smooth out those fluctuations. In other words, contrary to the traditional argument about the additional degrees of freedom for monetary policy provided by floating exchange rates, such a regime may in fact lead, in the presence of open capital accounts and inflation targeting, to pro-cyclical monetary policies. The only way to guarantee adequate degrees of freedom for countercyclical monetary policies may thus be to give up free floating, free capital mobility, or both.

The frequency of regimes with limited exchange rate flexibility (Reinhart and Rogoff, 2004) may be seen as a reflection of the revealed preference of authorities in the developing world for striking a balance between the conflicting demands they face by choosing intermediate exchange rate regimes. These regimes can take several forms: (a) quasi-fixed exchange rate regimes with large central bank interventions in foreign exchange markets; (b) managed exchange rates, such as crawling pegs and bands; and (c) dirty floats. ${ }^{2}$ All these regimes can be understood to include an element of "real exchange rate targeting" in the design of macroeconomic policy, and many or most of them are also mixed with different capital account regulations. According to the arguments presented above, this type of mix may be a rational choice when authorities face multiple objectives. Furthermore, to the extent that smoothing out real exchange rate fluctuations has a countercyclical effect, "real exchange rate targeting" can serve the objective of smoothing output volatility.

Thus, intermediate regimes may provide a better framework for effective "monetary autonomy" than floating exchange rates. This approach implies, of course, that monetary authorities will not have a single objective and that they will coordinate their actions with the fiscal authorities. Nonetheless, the scope for monetary autonomy is limited. First of all, that autonomy will depend on the effectiveness of capital account regulations as a macroeconomic policy tool, an issue we will deal with below. Secondly, all intermediate options are subject to speculative pressures if they do not generate credibility in markets, and the costs of defending the exchange rate are high in this context. This is particularly true of any pre-announcement (of the rate of the crawl, of a band, or of a specific exchange rate target), which should thus be avoided. Thirdly, intermediate regimes will generally require sterilized intervention in foreign exchange markets. Although the additional reserves accumulated during booms will provide additional "self-insurance" during the ensuing crises, the simultaneous accumulation of assets and liabilities in external currency generates quasi-fiscal losses.

In any case, one of the advantages of intermediate regimes is that they allow for a graduated flexibility, with the appropriate level of flexibility being determined by the relative benefits of stability vs. flexibility that we have analyzed. This implies that any specific intermediate regime has an embedded "exit option". Also, if some degree of exchange rate flexibility is available before an external crisis hits, this would provide scope to avoid the real interest rate overshooting that characterizes the transition towards freer exchange rates in developing countries. ${ }^{3}$

\footnotetext{
${ }^{2}$ For recent defences of intermediate regimes, see ECLAC (2000, chapter 8), Williamson (2000), Ocampo (2002) and Ffrench-Davis and Larraín (2003). For interesting reviews of recent controversies on exchange rate regimes, see Frankel (1999), Velasco (2000) and Braga de Macedo, et al. (2001).

${ }^{3}$ Indeed, the atypical phenomenon identified by Hausmann (2000)—when rising interest rates accompany the adoption of a more flexible exchange rate-is only a feature of transition periods.
} 


\section{Countercyclical fiscal policies}

Regardless of what exchange-rate and capital-account regime a country chooses, fiscal policy can always provide a useful countercyclical device. Indeed, it is frequently argued that fiscal policy is a more powerful countercyclical instrument than monetary policy in an open economy. But this argument runs against two strong facts.

The first is that there are objective restrictions on the capacity of fiscal policy to play a strong countercyclical role. Some of them are inherent to fiscal policy: spending inertia plays a very strong role in fiscal affairs, and there exist time lags between the point when a change in the course of policy becomes desirable and when either the government or parliament decides on the new course of action. Others are of a political economy character. In particular, there are objective limits to the capacity of fiscal authorities to convince the public that they should generate large fiscal surpluses during upswings in order to compensate rising private deficits (Marfán, 2005). The public may actually reject such a policy choice, given that it would generate substantial distributive effects, as the recipients of goods and services provided by the public sector are not the same agents that benefit from private spending. Furthermore, to the extent that social spending would be affected, the distributive effects of a spending cut would be regressive.

The second fact is that the pro-cyclical swings in external and domestic financing generate strong incentives for fiscal policies to behave in a pro-cyclical way. This is enhanced by the pro-cyclical performance of public sector revenues in the context of high GDP volatility, which implies that spending will be partly financed by temporary revenues during booms, and that temporary reductions in revenue will lead to procyclical cuts in spending. Also, the explosion of the debt service as a result of the variations of interest and exchange rates generated by adverse external shocks implies that primary fiscal spending must adjust pro-cyclically to meet short-term fiscal targets during crises. The orthodox expectation that cuts in the fiscal deficit will then "crowd in" private spending, thereby avoiding the contractionary effects of fiscal adjustment, is not generally met (see, for example, in relation to IMF programs, IMF, 2003).

At the same time, other pro-cyclical patterns have become more important than in the past, particularly those associated with the granting of explicit or implicit guarantees to the private sector. A first case in point are the explicit and implicit guarantees issued to financial agents and depositors in the financial system. These also include publicsector guarantees for private-sector investments in infrastructure (such as minimum revenue or profit guarantees, or explicit coverage of interest or exchange rate risks). Both types of guarantees have three elements in common: (a) they are not always transparent; (b) they encourage private spending during booms (it is during periods of euphoria that implicit public-sector spending, in the form of an equivalent "insurance premium", is actually incurred, indicating an underestimation of accrued public-sector spending during these periods); and (c) disbursements (cash spending) are incurred during crises, increasing borrowing requirements and crowding out other public-sector spending.

There is indeed widespread evidence that fiscal accounts are highly pro-cyclical in the developing world (Kaminsky, et al., 2004). In Latin America, for example, the evidence provided by Martner and Tromben (2003) indicate that out of 45 episodes of cyclical swings in 1990-2001, 12 were neutral (in the sense that the structural fiscal 
deficit remained unchanged through the improvement or deterioration of fiscal accounts), 25 were pro-cyclical and only 8 countercyclical.

The costs of pro-cyclical fiscal policies are high. Given the higher flexibility of public sector investment, they are likely to be reflected in large swings in this variable, a pattern that will tend to reduce its efficiency. During upswings, abundant financing may lead authorities to initiate some projects that have low social returns. During downswings, cuts in spending may mean that investment projects are left unfinished or take much longer to execute than planned, thereby raising their effective cost. In turn, extended cuts in public sector investment may have long-term effects on growth (Easterly and Servén, 2003; IMF, 2004a). To the extent that current spending is reduced during downswings, some valuable social programs may be cut, the existing structure for the provision of public and social services may become disjointed, and reductions in real wages may lead to the loss of valuable staff. Thus, in general, "stop-go" cycles significantly reduce the efficiency of public-sector spending.

This means that fiscal reforms must both firmly establish the principle of fiscal sustainability and adopt targets that avoid pro-cyclical biases in fiscal policy. Fiscal policies, however, cannot be expected to serve by themselves as the major instrument of countercyclical management, compensating not only the pro-cyclical effects of financial markets, but also those of pro-cyclical monetary and exchange rate policies.

The major reflection of the principle of fiscal responsibility should be the adoption of targets for the public sector deficit and/or maximum debt-to-GDP ratios. The definition of such rules is not an easy task, as indicated by the recent debates over the European Growth and Stability Pact (GSP). In any case (and contrary even to the practice of the GSP), deficit targets should be designed on the basis of the structural stance of fiscal policy. Indeed, setting fiscal deficit targets independently of the business cycle transforms fiscal policy into a pro-cyclical instrument, leading both to spending on the basis of transitory revenues during the boom and to cuts in spending during crises due to equally transitory reductions in revenue. The surplus or deficit target should then be determined on the basis of a structural stance and current deviations from potential GDP and other relevant variables. In this regard, an interesting experience in the developing world is that of Chile, which in recent years has set a structural public-sector surplus equivalent to 1 per cent of GDP.

Defining a structural stance is also a difficult task. In general, the trend of GDP growth will not be independent of cyclical swings, particularly in countries experiencing substantial shocks (Heyman, 2000). Furthermore, in developing countries, it would be important to determine also the cyclical stance of commodity prices that have a strong impact on public sector finances, but this is not easily done when these price deviations result from a random walk or from temporary deviations from a long-run trend, which may itself be subject to change.

A first major instrument of countercyclical policy is fiscal stabilization funds to sterilize temporary public-sector revenues (Davis, et al., 2003). The experience gained from the management of stabilization funds for commodities that have a significant fiscal impact (the National Coffee Fund of Colombia, and the copper and petroleum funds in Chile, for example) must be extended to develop broader fiscal stabilization funds (ECLAC, 1998). The counterpart of the resources accumulated in these funds would be 
sterilized foreign exchange reserves, which will then provide "self-insurance" against sudden stops of external financing, as well as reduced currency appreciation.

To the extent, however, that these funds sterilize the additional revenues generated by a commodity or capital boom, this would make fiscal policy at most cycle-neutral. A complementary instrument, of a clearly countercyclical character, would be to design flexible tax rates, particularly to manage sharp private sector spending cycles. The best candidate is obviously a tax on the source of the spending booms. This is the traditional argument for taxing exports subject to temporary price surges, which has served as the basis for the design of commodity stabilization funds. A similar argument can be used to justify a tax on capital inflows, as this is the major source of private-sector spending booms today (Marfán, 2005). ${ }^{4}$ It is interesting to note that this argument is additional to those associated with the greater monetary autonomy that such a tax on capital flows may provide. A second-best argument can also be made for temporary hikes of VAT rates during private spending booms (Budnevich and Le Fort, 1997).

To the extent that, as argued above, cyclical swings may reduce the efficiency of public sector spending and that time lags inevitably occur in the decision making process, the alternative of using discretionary changes in public spending as a countercyclical device is suboptimal. Indeed, a strong claim can be made that the growth of public-sector spending should be determined on the basis of an essentially long-term criterion: the balanced supply of public and private goods. In any case, a well-designed social safety net to protect vulnerable groups during crises (preferably as part of permanent social protection systems) is an automatic, countercyclical instrument that can play a useful macroeconomic (as well as social) role.

These tax and spending policies must be complemented by adequate mechanisms to manage public-sector guarantees. With respect to financial sector risks, regulatory policies are the proper answer. In the case of public sector guarantees of private infrastructure projects, it is necessary that the "insurance premium equivalent" of such guarantees be regularly estimated and budgeted, with the corresponding resources transferred to special funds created to serve as a backup in the event that the corresponding contingencies materialize. The estimated contingent liabilities should be added to the public sector debt. ${ }^{5}$

A major problem with these guarantees is that they generate significant distortions in public sector accounting. As argued earlier, they have pro-cyclical effects. If deficit targets are in place, the guarantees also clearly discriminate against public sector investment, for they create a strong incentive for governments to promote private investment in infrastructure to circumvent the targets. Dealing with all these issues simultaneously can only be achieved by combining a target for the current fiscal balance of the general public sector administration (such as a structural "golden rule"6 or a

\footnotetext{
${ }^{4}$ It should be emphasized that the tax collection could be done by the central bank (the equivalent tax for unremunerated reserve requirements on capital inflows), and the revenues could be sterilized in the form of a quasi-fiscal surplus not transferred to the government.

${ }^{5}$ The IMF (2004a) has argued that contingent liabilities should be included alongside public sector debt, but it does not propose similar treatment of the current account of the public sector. The treatment we propose here is more complete and symmetrical.

${ }^{6}$ This rule would determine that the current account of the general administration, including costs equivalent to the depreciation of the public sector capital stock, should be balanced, once cyclical factors are netted out.
} 
structural primary surplus) with a public sector debt target that includes all contingent liabilities. Also, to avoid discriminating against investment by public sector firms vs. private investment in infrastructure, the same criteria must be used in both cases: the fiscal risk incurred by the public sector administration in either case. ${ }^{7}$ Indeed, the only other option is a full accounting of guaranteed private sector investments within fiscal targets.

\section{Capital management techniques}

\section{The case for capital-account regulations}

The accumulation of macroeconomic risks during booms depends not only on the magnitude of private- and public-sector debts, but also on the maturity and currency mismatches on their balance sheets. Therefore, capital-account regulations potentially have a dual role: as a macroeconomic policy tool which provides some room for countercyclical monetary policies that smooth out spending and avoid excessive debt ratios, and as a "liability policy" which encourages improvements in private-sector external debt profiles. The emphasis on liability structures, rather than on national balance sheets, recognizes the fact that, together with liquid assets (particularly international reserves), the liability structures play the crucial role when countries face liquidity constraints; other assets play a secondary role in this regard.

Viewed as a macroeconomic policy tool, capital-account regulations target the direct source of boom-bust cycles: unstable capital flows. If successful, they will provide some room to "lean against the wind" during periods of financial euphoria, through the adoption of a contractionary monetary policy and/or reduced appreciation pressures. If effective, they will also reduce or eliminate the quasi-fiscal costs of foreign-exchange reserve accumulation. During crises, they provide "breathing space" for expansionary monetary policies. In both cases, capital-account regulations improve the authorities' ability to mix a countercyclical monetary policy with a more active exchange rate policy.

Viewed as a liability policy, capital-account regulations recognize the fact that the market rewards sound external debt profiles (Rodrik and Velasco, 2000). This reflects the fact that, during times of uncertainty, the market responds to gross (rather than merely net) financing requirements, which means that the rollover of short-term liabilities is not financially neutral. Under these circumstances, a maturity profile that leans towards longer-term obligations will reduce domestic liquidity risks. This indicates that an essential component of economic policy management during booms should be instruments that improve the maturity structures of the external and domestic liabilities of both the private and public sectors. On the equity side, foreign direct investment (FDI) should be preferred to portfolio flows, as the former has proved to be less volatile than the latter. Both types of equity flows have the additional advantage of allowing all risks associated with the business cycle to be shared with foreign investors, and FDI may bring other benefits (access to technology and external markets). These benefits should be balanced against the generally higher costs of equity financing.

\footnotetext{
${ }^{7}$ This rule would be simpler and much better than the stringent criteria suggested by the IMF (2004a) to determine whether an investment by a public sector firm will be excluded from the public sector accounts. The latter includes criteria that may be contrary to the legal principles that define a public sector firm in some countries, and that have nothing to do with the fiscal risks incurred (such as total managerial independence, stock listing and rights of minority shareholders).
} 
In macroeconomic terms, capital market regulations work by segmenting the domestic capital market from international markets. As such, it can be seen as a "second best" policy that aims to correct the fundamental market failures identified above: the inability of most countries to issue liabilities in international markets denominated in their domestic currencies ("original sin"), and the under-supply of long-term financing in these currencies (the greater "incompleteness" of domestic capital markets). A "first best" solution would require at least three conditions: (a) the creation of a long-term demand for domestic-currency-denominated assets abroad, a measure that may be impossible according to the "original sin" literature; (b) coverage of the risks incurred by domestic agents with either international reserves (a costly "self-insurance" device) or with debt issued in the domestic currency by multinationals (an option that has been available to some countries according to the same literature - see Hausman and Panizza, 2003); and (c) the development of deep markets for long-term debt and securities in domestic currencies. But some of these solutions are either unavailable or take a long time to develop. Capital account regulations thus recognize that, given the existing segmentation, it may be optimal to respond to this market imperfection by further segmenting the market through regulations, rather than designing economic policy as if such segmentation did not exist.

Traditional controls-which many developing countries, including major ones (such as China and India), continue to use in diverse ways-basically work by segmenting the domestic and foreign capital markets through rules that openly differentiate between residents and non-residents and, among the former, between corporate and non-corporate residents. This includes forbidding domestic firms and residents from borrowing in foreign currency, except for some specific transactions (trade financing and long-term investment) by some agents (corporations), subject perhaps to ceilings. The rules also forbid foreign residents from holding assets or debt denominated in the domestic currency, except for the domestic operations of foreign investors (and even in this case debts may be restricted or forbidden). Finally, they prohibit domestic banks from holding deposits by residents in foreign currencies or from lending in foreign currencies (except when intermediating the allowed external credit lines).

For countries that choose to be more fully integrated into international capital markets, the possibilities are varied and can be combined in different forms. A first option is to introduce rules not unlike traditional quantitative (administrative) controls that temporarily segment the market between residents and non-residents; this was Malaysia's choice in 1994 (in relation to inflows) and 1998 (to outflows). Another option is to introduce price-based regulations that effectively tax inflows or outflows. Taxing inflows was the choice pioneered by Chile in 1991 and Colombia in 1993 (where it was applied more aggressively), using the mechanism of an unremunerated reserve requirement (URR) on capital inflows; in both cases, URRs were reduced and eventually dismantled during the Asian crisis. Taxing outflows was introduced by Malaysia in February 1999 as a substitute for its 1998 regulations; the exit tax was then gradually reduced until it was dismantled in May 2001. The basic advantage of price-based regulations is their non-discretionary character.

Other rules, which can be combined with any of the previous two systems or can stand by themselves, include more permanent prohibitions or strong discouragement of domestic financial dollar/euro-ization, and of offshore markets and the international use 
of the domestic currency (strongly discouraged by the Singaporean authorities and part of the 1998 Malaysian controls). Also, portfolio flows can be subject to direct regulation, in terms of the amounts that can be brought into the country and the domestic securities in which they can invest (as in Colombia). Direct borrowing abroad or issuance of ADRs and similar instruments may be subject to prudential regulations that apply to the issuer. And minimum stay requirements can be established (as in Chile, where the requirement was lifted in May 2000).

A comparative evaluation of these experiences leads to four major conclusions. ${ }^{8}$ First of all, controls on both inflows and outflows can work, but it is essential to build the capacity to administer the regulations, while avoiding loopholes and, particularly, corruption. As the experience of Malaysia indicates, however, no direct previous experience of capital account regulations is necessary for success. In this regard, according to IMF evaluations, simple traditional quantitative restrictions that rule out certain forms of indebtedness may be easier to administer than price-based controls (Ariyoshi, et al., 2000) and may thus be preferable for countries with weaker administrative capacity. Also, in countries characterized by deeper domestic financial development, it may be easier to circumvent controls, but some tools may work even under those conditions, as the experiences of Chile and Malaysia indicate. A good administration requires, however, dynamic adjustment to close loopholes and, generally, to respond to changing market conditions. For this reason, maintaining permanent regulatory regimes that are tightened or loosened through the business cycle or in response to other market conditions may be better than alternating different capital account regimes.

Secondly, in terms of macroeconomic effectiveness, traditional exchange controls and capital-account regulations may be the best option if the policy objective is to reduce significantly the domestic sensitivity to international capital flows. This is reflected, in particular, in the lower sensitivity to such flows during the Asian crisis by countries that maintained more traditional regulations vis-à-vis Latin American countries that used price-based regulations. Also, a comparative analysis of the price-based controls of Chile and Colombia vs. the quantity-based controls of Malaysia indicates that the Malaysian controls had stronger effects on the magnitude of capital flows (inflows or outflows, depending on the target variable) and, more generally, on compensating the expansionary or contractionary macroeconomic pressures generated by the capital account (Ocampo, 2003a; Ocampo and Palma, 2004). Despite the fact, however, that URRs may have only temporary effects on capital inflows (if they are not dynamically reinforced in the face of a continuous capital surge), they are not ineffective in macroeconomic terms. In particular, there is strong evidence that they influence interest rate spreads. ${ }^{9}$ Thus, in broader terms, the usefulness of URR as a macroeconomic policy tool is reflected in the capacity to affect capital flows, domestic interest rates, or both, with the particular combination subject to other macroeconomic conditions and to policy choice.

\footnotetext{
${ }^{8}$ See, in this regard, the comparative evaluations of some of these experiences by Ariyoshi, et al. (2000), Epstein, et al. (2003 and 2004), Ocampo (2003a), Ocampo and Palma (2004), Palma (2002) and Rajaraman (2001). See also the evaluation of the Indian experience by Nayyar (2002) and Reddy (2001), and that of the Malaysian experience by Kaplan and Rodrik (2001).

${ }^{9}$ See De Gregorio, et al. (2000) in relation to Chile, and Villar and Rincón (2003) in relation to Colombia. This is also the interpretation of the Chilean experience provided by Williamson (2000, ch. 4). Indeed, according to this interpretation, the conflicting evidence on the Chilean system largely disappears.
} 
Thirdly, contrary to the heated controversies regarding the macroeconomic effectiveness of reserve requirements, particularly of URRs, broad agreement exists on their effectiveness in reducing short-term debt flows and thus in improving or maintaining good external debt profiles. As such, they have proven to be a useful preventive macroeconomic policy tool.

Finally, it is important to emphasize that capital-account regulations should be seen - and, in fact, have been seen by countries adopting them-, not as a substitute for, but as a complement to other "sound" macroeconomic policies. Moreover, they improve fundamentals. In particular, they provide additional degrees of freedom to adopt countercyclical macroeconomic policies.

It should probably be emphasized that, in order to guarantee the effectiveness of capital account regulations, some regulations on current-account transactions (export surrender requirements or the obligation to channel trade transactions through certain approved intermediaries) may be necessary. As already pointed out, it is also essential to avoid the internationalization of the domestic currency and domestic financial dollar/euro-ization (Reddy, 2001).

Prudential regulation and supervision can complement but also partly substitute for the role played by capital-account regulations. Indeed, the distinction between capital controls and prudential regulations affecting cross-border flows is not so clear cut. In particular, higher liquidity (or reserve) requirements for the financial system's foreigncurrency liabilities can be established, and domestic lending to firms operating in nontradable sectors can be forbidden or those firms can be discouraged from borrowing in foreign currencies, through more stringent regulatory provisions on the financial intermediaries involved in the transaction.

The main problem with these options is that they only indirectly affect the foreign-currency liabilities of non-financial agents and, indeed, may encourage them to borrow directly abroad. Accordingly, they need to be supplemented with other regulations, including rules on the types of firms that can borrow abroad and prudential ratios with which they must comply; restrictions on the terms of corporate debts that can be contracted abroad (minimum maturities and maximum spreads); public disclosure of the short-term external liabilities of firms; regulations requiring rating agencies to give special weight to foreign exchange exposure; and tax provisions applying to foreigncurrency liabilities (see, on the latter, Stiglitz and Bhattacharya, 2000). Some of the most important regulations of this type concern external borrowing by firms operating in nontradable sectors. A simple rule that should be considered is the strict prohibition against borrowing in a foreign currency by non-financial firms with no foreign currency revenues. Alternatively, restrictions could be placed on the maturities (only long term) or end use (only investment) of such borrowing. Price-based capital-account regulations may thus be simpler to administer than an equivalent system based on prudential regulations and additional policies aimed at non-financial firms.

Capital controls obviously have costs. First, they increase the costs of financing during capital surges. ${ }^{10}$ This is precisely the desired effect, however, as the increase in those costs has the expected countercyclical effect. A second, longer-term effect may be the impact of controls on domestic financial development. Derivatives markets will have more limited room to develop, and the operations of foreign institutional investors that

\footnotetext{
${ }^{10}$ Given asymmetries in direct access to external markets, this effect may disproportionately affect SMEs.
} 
may act as "market makers" in domestic capital markets will be restricted. The tradeoffs that authorities face in the short run are not simple in this regard, but authorities should clearly aim to avoid the adverse effects that controls can have on the development of deeper, liquid domestic capital markets.

\section{The macroeconomic dimensions of prudential regulations}

The origins of problems that erupt during financial crises are associated with both excessive risk-taking during booms, as reflected in a rapid increase in lending, and with the inevitable mix of maturity and currency mismatches that characterize balance sheets in developing countries. Inadequate risk analysis by financial agents and weak prudential regulation and supervision of domestic financial systems exacerbate this problem. This issue became evident during the first wave of financial crises that hit Latin America in the early 1980s (Díaz-Alejandro, 1988, ch. 17), but it was broadly ignored in later episodes of financial liberalization in the developing world. Since the Asian crisis, the principle that financial liberalization should take place within a suitable institutional setting has been firmly adopted. Indeed, it is now widely recognized that properly regulated and supervised financial systems are structurally superior in terms of risk management.

Prudential practices have traditionally focused on microeconomic risks. In recent years, however, increasing attention has been placed on risks that have a clear macroeconomic origin. The basic problem in this regard is the inability of individual financial intermediaries to internalize the collective risks assumed during boom periods, giving rise to coordination problems beyond the control of any single agent. In terms of the terminology used in portfolio risk management, whereas microeconomic risk management can reduce non-systematic risks (those that depend on individual characteristics of each borrower) through diversification, they cannot reduce systematic risks (those associated with common factors that market agents face, such as economic policy and the business cycle).

Moreover, traditional regulatory tools, including both Basle I and Basle II standards, have a pro-cyclical bias. ${ }^{11}$ The basic problem in this regard is the highly procyclical nature of a system in which loan-loss provisions are tied to loan delinquency or to short-term expectations of future loan losses. Under this system, the precautionary signals may be ineffective in hampering excessive risk-taking during booms, when expectations of loan losses are low. On the other hand, the sharp increase in loan delinquency during crises reduces financial institutions' capital and, hence, their lending capacity, possibly triggering a "credit squeeze"; this reinforces the downswing in economic activity and asset prices and, thus, the quality of the portfolios of financial intermediaries. ${ }^{12}$ These problems may be particularly severe in developing countries, where due attention should thus be given to the links between domestic and external

\footnotetext{
${ }^{11}$ For recent analyses of these issues and policy options for managing them, see BIS (2001, ch. VII); Borio, et al. (2001), and Clerc, et al. (2001). In relation to Basle II, see Griffith-Jones, et al. (2003) and United Nations (2003, pp. 54-57). Since credit ratings are also pro-cyclical, basing risk on such ratings, as proposed by Basle II, is also a pro-cyclical practice.

${ }^{12}$ For this reason, the sudden introduction of strong regulatory standards during crises may worsen a credit squeeze. Thus, although authorities must adopt clearly defined rules to restore confidence, the application of stronger standards should be gradual. In any case, to avoid moral hazard problems, authorities must never bail out the owners of financial institutions.
} 
financing; the links among these two factors, asset prices and economic activity; and the links between domestic financial risks and variations in interest and exchange rates.

Given the central role that all of these processes play in the business cycles of developing countries, the crucial issue is to introduce a countercyclical element into prudential regulation and supervision. In this regard, the major innovation is the Spanish system of forward-looking provisions, introduced in December 1999. According to this system, provisions are made when loans are disbursed based on the expected ("latent") losses; such "latent" risks are estimated for homogenous categories of credit, estimated on the basis of a full business cycle (Poveda, 2000; Fernández de Lis, et al., 2001). This system implies, in fact, that provisioning follows the criteria traditionally used by the insurance industry (where provisions are made when the insurance policy is issued), rather than by the banking industry (where they are made when loans become due).

Under this system, provisions ${ }^{13}$ build up during economic expansions and are drawn upon during downturns. They are accumulated in a fund, together with special provisions (traditional provisions for non-performing assets or for borrowers under stress) and recoveries of non-performing assets. The fund can be used to cover loan losses, thus in effect entirely substituting for special provisions if resources are available in adequate amounts. Although the accumulation and drawing down of the fund has a countercyclical dynamic, this only reflects the cyclical pattern of bank lending. Thus, the system is, strictly speaking, "cycle-neutral", rather than countercyclical, but it is certainly superior to the traditional pro-cyclical provisioning for loan losses or forward-looking provisioning based on shorter time horizons.

Therefore, such a system should be complemented by strictly countercyclical prudential provisions, which can be decreed by the regulatory authority for the financial system as a whole or for some sectors or economic agents, or by the supervisory authority for special financial institutions on the basis of objective criteria. These criteria could include the excessive growth of credit (relative to some benchmark), the bias in lending to sectors characterized by systematic risks and the growth of foreign-currency denominated loans to non-tradable sectors.

A system of provisions such as this is certainly better than the possible use of capital adequacy ratios to manage the effects of business cycles. Capital adequacy requirements should focus instead on long-term solvency criteria, rather than on cyclical performance. Insofar as developing countries are likely to face more macroeconomic volatility, a case could be made for requiring higher capital/asset ratios (see additional arguments below), but no convincing case exists for capital adequacy requirements, as such, to be countercyclical. Focusing on provisions rather than capital requirements has an additional advantage, in that the quality of the capital may be difficult to guarantee in developing countries (Rojas-Suarez, 2004).

These provisions should be supplemented by more specific regulations aimed at controlling currency and maturity mismatches (including those associated with derivative operations), and at avoiding the overvaluation of collateral generated by asset price bubbles. The strict prohibition of currency mismatches in the portfolios of financial intermediaries is the best rule. As we have seen, authorities should also closely monitor

\footnotetext{
${ }^{13}$ Under this system, provisions are estimated using either the internal risk management model of the financial institution or the standard model proposed by Banco de España. The latter establishes six categories, with annual provisioning ratios that range from 0 per cent to 1.5 per cent.
} 
the currency risk of non-financial firms operating in non-tradable sectors, which may eventually become credit risks for banks. Regulations can be used to establish more stringent provisions and/or risk weighting for these operations, or a strict prohibition on lending in foreign currencies to non-financial firms without revenues in those currencies.

In addition, prudential regulation needs to ensure adequate levels of liquidity for financial intermediaries so that they can handle the mismatch between the average maturities of assets and liabilities, which is inherent in the financial system's essential function of transforming maturities, and which generates risks associated with volatility in deposits and/or interest rates. This underscores the fact that liquidity and solvency problems are far more closely interrelated than traditionally assumed, particularly in the face of macroeconomic shocks. Reserve requirements, which are strictly an instrument of monetary policy, provide liquidity in many countries, but their declining importance makes it necessary to find new tools. Moreover, their traditional structure is not geared to the specific objective of ensuring financial intermediaries' liquidity in the face of the inherent maturity mismatches in their portfolios. The best system could be one in which liquidity or reserve requirements are estimated on the basis of the residual maturity of financial institutions' liabilities, thus generating a direct incentive for the financial system to maintain an appropriate liability structure.

The valuation of assets used as collateral for loans also presents problems when these assets exhibit price volatility because, in many cases, prices used to value collateral may be significantly higher than ex-post prices. Limits on loan-to-value ratios and/or rules to adjust the values of collateral for cyclical price variations should be adopted.

It must be emphasized, in any case, that any regulatory approach has clear limits and costs that cannot be overlooked. Prudential regulation involves some non-price signals, and prudential supervision is full of information problems and is a discretionary activity susceptible to abuse. Experience also suggests that even well regulated systems in industrial countries are subject to periodic episodes of euphoria, when risks are underestimated. The recent crisis in Argentina is a specific case in which a system of prudential regulations considered to be one of the best in the developing world - and working within the framework of a financial sector characterized by the large-scale presence of multinational banks - clearly failed to avert the effects of major macroeconomic shocks on the domestic financial system.

Moreover, many regulatory practices aimed at correcting risky practices on the part of financial intermediaries shift the underlying risks to non-financial agents, rather than eliminate them. This may generate indirect credit risks. Thus, for example, lower risk ratings for short-term credit and strong liquidity requirements reduce direct banking risks, but they also reinforce the short-term bias in lending. Maturity mismatches are thus displaced to non-financial agents and may result in reduced fixed capital investment. Also, prudential regulations forbidding banks from holding currency mismatches in their portfolios may encourage non-financial agents to borrow directly from abroad. The higher spreads that stricter prudential regulation entails generate a similar incentive. As we have seen, the risks assumed by corporations operating in non-tradable sectors will eventually be translated into the credit risk of domestic financial institutions that are also their creditors. In all these cases, therefore, the reduced direct vulnerability of the domestic financial sector will have, as a corollary, the maturity and currency mismatches of non-financial agents. 


\section{Public-sector liability management}

In any developing country, the public sector faces some of the most severe maturity and currency mismatches. Its investments are long-term in character and, except in the case of a few public-sector firms, it produces non-tradable goods and services. Beyond that, moral hazard issues are paramount. Thus, specific legal limits and regulations are required, although, as argued here, strong fiscal responsibility laws can help maintain healthy debt ratios and structures by establishing clear rules on public sector indebtedness, direct mechanisms for controlling foreign borrowing, and rules establishing minimum maturities and maximum spreads at which public sector entities can borrow. The Ministry of Finance or the central bank can play a leading role in either of these areas, establishing rules that should apply not only to the central administration, but also to autonomous public-sector agencies and sub-national governments.

Several financial crises have underscored the importance of the maturity structure of the domestic liabilities of the public sector. The basic reason for this is the highly liquid nature of public-sector securities, which facilitates asset substitution and, thus, capital flight. Thus, when gross borrowing requirements are high, the interest rate will have to increase to make debt rollovers attractive. Higher interest rates will then feed into the budget deficit, contributing to the rapid increase of debt service and the acceleration of indebtedness. In addition, rollovers may be viable only if risks of devaluation or future interest rate hikes can be transferred to the government, thus generating additional sources of destabilization. This was the case prior to the Mexican crisis of 1994 and the Brazilian crisis of 1999, when fixedinterest bonds were swiftly replaced by variable-rate and dollar-denominated securities. On the contrary, given Colombia's tradition of issuing public-sector securities with a minimum one-year maturity, no substitution of a similar magnitude was observed in this country during its 1998-99 crisis (Ocampo, 2003a).

Although the currency mismatches that characterize the public sector would recommend borrowing exclusively in the domestic currency, there are two reasons why this rule should not be strictly followed. The first one is macroeconomic in character: the public sector can play an essential role in compensating the highly pro-cyclical pattern of external private capital flows. This means that, during capital-account surges, the public sector should adopt a liability policy aimed at substituting external for domestic liabilities. In contrast, during phases of reduced private capital inflows, the public sector may be one of the best net suppliers of foreign exchange, thanks to its preferential access to external credit, including that from multilateral financial institutions. Such borrowing may also be helpful in maintaining a better external debt profile and avoiding private borrowing abroad at excessively high spreads during crises.

The second reason relates to the depth of domestic bond markets, which determines the ability to issue longer-term domestic debt securities. This attribute includes the existence of secondary markets and market makers that provide liquidity for these securities. In the absence of these pre-conditions, the government faces a serious trade-off between maturity and currency mismatches. It may thus make sense to opt for a debt mix that includes an important component of external liabilities, despite the associated currency mismatch. In the long run, the objective of the authorities should be, in any case, to deepen the domestic capital markets. Indeed, due to the lower risk levels and the greater homogeneity of the securities it issues, the central government has a vital 
function to perform in the development of longer-term primary and secondary markets for domestic securities, including the creation of benchmarks for private-sector debt instruments.

\section{In Lieu Of Conclusions}

A major conclusion of this paper is that a broad view of macroeconomic stability is essential to the design of "sound" macroeconomic frameworks. Such a framework necessarily involves multiple objectives and significant tradeoffs. This implies that, although a broad focus on sustainability, including external, fiscal and financial sector sustainability, is correct (IMF, 2004b), equally important emphasis should be given to the countercyclical dimensions of macroeconomic and financial policies.

Managing such countercyclical frameworks policies is no easy task. Given existing asymmetries in the international economic order, financial markets generate strong pro-cyclical effects and strong incentives to follow pro-cyclical policy rules in the developing world. Moreover, globalization places objective limits on national macroeconomic policy autonomy. In this context, as we have seen, self-insurance is costly and may merely shift the underlying macroeconomic and financial risks, rather than correct them. For this reason, international cooperation in the macroeconomic policy area should be designed with the clear objective of overcoming these incentives and constraints.

This means that the first role of international financial institutions, from the point of view of developing countries, is to counteract the pro-cyclical effects of financial markets. This can be achieved by smoothing out boom-bust cycles at their source through regulation, and by increasing the incentives and degrees of freedom that developing countries have to adopt countercyclical policies. This should be done through adequate surveillance and incentives to avoid the build-up of risky macroeconomic and financial conditions during periods of financial euphoria, together with sufficient financing and appropriate debt management and restructuring mechanisms that avoid the explosive debt dynamics that characterize periods of sudden stops of external financing. As is well known, major issues in these areas are the weak signals that surveillance may give in a period of financial euphoria; the absence of some essential lending facilities (such as the failed contingency credit line or an invigorated contingency financing facility) and limits on the use of others, matters which have been the subject of recurrent debate in the IMF Board in recent years; and the absence of an agreed international framework for debt standstills, write-offs and rescheduling. A second and equally essential role of international financial cooperation is to counter the concentration of lending by providing access to those countries and agents that tend to be subject to rationing in private international capital markets. This is, of course, a persistent problem for some developing countries (the poorest among them), but a cyclical one for others (the "emerging market" economies). Lending should therefore follow a countercyclical pattern, not only in the case of the IMF (a fact that is widely recognized), but also of multilateral development banks. ${ }^{14}$

Development banks can also help to create new financial instruments with a clear countercyclical focus. Particularly, government counterpart funds can be temporarily detached from bank disbursements to generate these effects. Thus, governments can

\footnotetext{
${ }^{14}$ For an analysis of some of these issues, see Griffith-Jones and Ocampo (2003).
} 
actually "save" counterpart funds in multilateral banks during booms for disbursement, together with bank financing, during crises. This would be a particularly effective instrument for the design of social safety net financing. Also, greater use could be made of contingency repayment clauses, according to which loan amortization would be accelerated or slowed down on the basis of some indicators of GDP growth, terms of trade or the availability of private external financing. Development banks could also play a role as "market makers" for new private sector lending instruments that reduce developing country risks, such as GDP-linked and commodity-linked bonds.

This leads to two interesting implications of the analysis of the asymmetries in financial markets that underlie the pro-cyclical risks that developing countries face. The first is related to the "original sin". Although it is possible to think of private funds that, by spreading risk among a large number of currencies, can lend in the currencies of the developing countries (Dodd and Spiegel, 2004), such funds have not developed in a significant way. Thus, their promotion by multilateral development banks and direct lending by them in the currencies of developing countries seem to offer a partial road to "redemption". If multilateral development banks want to cover the risks of such currency exposure, they can become important players in the development of long-term security markets in developing countries' currencies; some have already started to play this role. The second implication is closely related. The analysis presented in this paper indicates that there is no substitute for long-term lending in the domestic currencies of developing countries. The development of deep domestic financial markets in the currencies of developing countries should thus be strongly supported by the international financial institutions. An essential corollary of this statement is that reversing (and, obviously, avoiding new cases of) dollar/euro-ization should be an element of that support.

The macroeconomic toolkit of developing countries must be preserved and even enhanced. This means that developing countries should maintain the autonomy to impose capital-account regulations, and thus, the freedom to re-impose controls if they deem them useful. It also means that the tools for financial sector management should be improved. Since the Asian crisis, this has been, of course, a centrepiece of the IMF/World Bank's Financial Sector Assessment Program, as well as of their technical assistance activities. Nonetheless, this paper shows that much more emphasis should be given to forward-looking provisioning and other countercyclical tools of prudential regulation, which have not received adequate attention. Indeed, experience and analysis (including recent debates on Basle II) indicate that traditional regulatory instruments may increase, rather than reduce pro-cyclicality.

Finally, this paper also suggests that, given the multiple objectives and tradeoffs faced by macroeconomic authorities, solutions are likely to differ according to the conditions that characterize each country. This means not only that "one size fits all" solutions are entirely inadequate, but also, and very importantly, that the principle of "ownership" by developing countries of their macroeconomic policies should be strictly respected.

\section{References}

Ariyoshi, Akira, Karl Habermeier, Bernard Laurens, Inci Ötker-Robe, Jorge Iván Canales-Kriljenko, and Andrei Kirilenko (2000). "Capital Controls: Country 
Experiences with Their Use and Liberalization”. Occasional Paper No. 190, International Monetary Fund, Washington, D.C.

BIS (2001). $71^{\text {st }}$ Annual Report. June, Bank for International Settlements, Basle.

Bordo, Michael, Barry Eichengreen, Daniela Klingebiel and María Soledad MartínezPeria (2001). "Is the Crisis Problem Growing More Severe?". Economic Policy 32, April: 51-82.

Borio, Claudio, Craig Furfine and Philip Lowe (2001). "Pro-cyclicality of the Financial System and Financial Stability: Issues and Policy Options". In Marrying the Macro- and Micro-Prudential Dimensions of Financial Stability. BIS Paper No. 1, March, Bank for International Settlements, Basel: 1-57.

Braga de Macedo, Jorge, Daniel Cohen and Helmut Reisen (eds) (2001). "Monetary Integration for Sustained Convergence: Earning Rather than Importing Credibility”. In Jorge Braga de Macedo and others (eds). Don't Fix, Don't Float. OECD Development Centre Studies, Paris: 11-53.

Calvo, Guillermo (2001). "The Case for Hard Pegs in the Brave New World of Global Finance”. In Jorge Braga de Macedo and others (eds). Don't Fix, Don't Float. OECD Development Centre Studies, Paris: 77-84.

Calvo, Guillermo, Leonardo Leiderman, and Carmen Reinhart (1993). "Capital Inflows and Real Exchange Rate Appreciation in Latin America: The Role of External Factors". IMF Staff Papers 40, March: 108-151.

Calvo, Guillermo, and Ernesto Talvi (2004). "Sudden Stop, Financial Factors and Economic Collapse: A View from the Latin American Frontlines". Paper presented in the Universal Forum for Cultures, Barcelona, September.

Clerc, Laurent, Françoise Drumetz and Oliver Jaudoin (2001). "To What Extent are Prudential and Accounting Arrangements Pro- or Countercyclical with Respect to Overall Financial Conditions?". In Marrying the Macro- and Micro-Prudential Dimensions of Financial Stability. BIS Papers No. 1, March, Bank for International Settlements, Basel: 197-210.

Davis, Jeffrey, Rolando Ossowski, James A. Daniel and Steven Barnett (2003). "Stabilization and Savings Funds for Nonrenewable Resources: Experience and Fiscal Policy Implications". In Jeffrey Davis, Rolando Ossowski and Annalisa Fedelino (eds). Fiscal Policy Formulation and Implementation in Oil-Producing Countries. International Monetary Fund, Washington, D.C., Chapter 11.

De Gregorio, José, Sebastián Edwards and Rodrigo Valdés (2000). "Controls on Capital Inflows: Do They Work?’. Journal of Development Economics 63 (1), October: 59-83.

Díaz-Alejandro, Carlos F. (1988). Trade, Development and the World Economy: Selected Essays. Andrés Velasco (ed.). Basil Blackwell, Oxford.

Dodd, Randall, and Shari Spiegel (2004). "Up From Sin: A Portfolio Approach to Salvation". Paper prepared for the XVIII Technical Group Meeting of the Group of 24, Geneva, March.

Easterly, William (2001). The Elusive Quest for Growth. MIT Press, Cambridge. Easterly, William, Roumeen Islam and Joseph E. Stiglitz (2001). "Shaken and Stirred: Explaining Growth Volatility". In Boris Pleskovic and Nicholas Stern (eds). Annual Bank Conference on Development Economics 2000. World Bank, Washington, DC.: 191-211. 
Easterly, William, and Luis Servén (eds) (2003). The Limits of Stabilization:

Infrastructure, Public Deficits, and Growth in Latin America. Stanford University

Press, Palo Alto, and World Bank, Washington, D.C.

ECLAC (2000). Equity, Development and Citizenship. Economic Commission for Latin America and the Caribbean, Santiago.

ECLAC (1998). The Fiscal Covenant: Strengths, Weaknesses, Challenges. Economic Commission for Latin America and the Caribbean, Santiago.

Eichengreen, Barry, Ricardo Hausman and Ugo Panizza (2003). "Currency Mismatches, Debt Intolerance and Original Sin: Why they are not the same and why they matter". NBER Working Paper 10036, October, National Bureau for Economic Research, Cambridge, MA.

Epstein, Gerald, Ilene Grabel and K.S. Jomo (2003). "Capital Management Techniques in Developing Countries". In Ariel Buira (ed.). Challenges to the World Bank and the IMF: Developing Country Perspectives. Anthem Press, London: Chapter 6.

Epstein, Gerald, Ilene Grabel and K.S. Jomo (2004). "Capital Management Techniques in Developing Countries: Managing Outflows in Malaysia, India and China". Processed, Initiative for Policy Dialogue, Columbia University.

Fernández de Lis, Santiago, Jorge Martínez and Jesús Saurina (2001). "Credit Growth, Problem Loans and Credit Risk Provisioning in Spain". In Marrying the Macroand Micro-Prudential Dimensions of Financial Stability. BIS Paper No. 1, March, Bank for International Settlements, Basel: 310-30.

Ffrench-Davis, Ricardo (2001). Financial Crises in 'Successful' Emerging Economies. Brookings Institution Press, Washington, D.C. and ECLAC, Santiago.

Ffrench-Davis, Ricardo, and Guillermo Larraín (2003). "How Optimal are the Extremes? Latin American Exchange Rate Policies during the Asian Crisis". In Ricardo Ffrench-Davis and Stephany Griffith-Jones (eds). From Capital Surges to Drought: Seeking Stability for Emerging Markets. Palgrave Macmillan, London: 245-68.

Frankel, Jeffrey (1999). No Single Currency Regime Is Right for All Countries or at All Times. Essays in International Finance No. 215, International Finance Section, Department of Economics, Princeton University, Princeton, NJ.

Frenkel, Roberto (2005). "External Debt, Growth and Sustainability". In José Antonio Ocampo (ed.). Beyond Reforms: Structural Dynamics and Macroeconomic Vulnerability. Stanford University Press, Palo Alto, and Economic Commission for Latin America and the Caribbean, Santiago: 189-209.

Frenkel, Roberto (2004). "Real Exchange Rate and Employment in Argentina, Brazil, Chile and Mexico". Paper prepared for the Group of 24, Washington, DC, September.

Griffith-Jones, Stephany, and Avinash Persaud, with Stephen Spratt and Miguel Segoviano (2003). "The Pro-cyclical Impact of Basel II on Emerging Markets and its Political Economy". Paper prepared for the Economic Commission for Latin America and the Caribbean, Santiago.

Griffith-Jones, Stephany, and José Antonio Ocampo (2003). What Progress on International Financial Reform? Why So Limited? Almqvist \& Wiksell International, Stockholm, for Expert Group on Development Issues (EGDI). 
Hausmann, Ricardo (2000). "Exchange Rate Arrangements for the New Architecture". In Global Finance from a Latin American Viewpoint. Inter-American Development Bank (IDB), and Organization for Economic Co-operation and Development (OECD), Paris: 81-94.

Hausmann, Ricardo, and Ugo Panizza (2003). "On the Determinants of Original Sin: An Empirical Investigation”. Journal of International Money and Finance 22: 95790.

Heyman, Daniel (2000). "Major macroeconomic upsets, expectations and policy responses". CEPAL Review 70: 13-29.

IMF (1998). World Economic Outlook, 1998 - Financial Crises: Characteristics and Indicators of Vulnerability. May, International Monetary Fund, Washington, DC.

IMF (2003). Fiscal Adjustment in IMF-Supported Programs. Independent Evaluation Office, International Monetary Fund, Washington, DC.

IMF (2004a). "Public Investment and Fiscal Policy". Document presented to the Board, March 12, International Monetary Fund, Washington, DC.

IMF (2004b). "Assessing Sustainability". Document presented to the Board, May 28, International Monetary Fund, Washington, DC.

Kaminsky, Graciela L., Carmen M. Reinhart and Carlos A. Végh (2004). "When It Rains, It Tours: Pro-cyclical Capital Flows and Macroeconomic Policies". NBER Working Paper No. 10780, September, National Bureau for Economic Research, Cambridge, MA.

Kaplan, Ethan and Dani Rodrik (2001). "Did the Malaysian Capital Controls Work?". NBER Working Paper No. 8142, February, National Bureau for Economic Research, Cambridge, MA.

Krugman, Paul (1990). Rethinking International Trade. MIT Press, Cambridge.

Krugman, Paul, and Lance Taylor (1978). "Contractionary effects of devaluations". Journal of International Economics 8: 445-56.

Larraín, Felipe, Raúl Labán and Rómulo Chumacero (2000). "What Determines Capital Inflows? An Empirical Analysis for Chile". In Felipe Larraín (ed.). Capital Flows, Capital Controls, and Currency Crises: Latin America in the 1990s. University of Michigan Press, Ann Arbor: 61-82.

Marfán, Manuel (2005). "Fiscal Policy, Efficacy and Private Deficits: A Macroeconomic Approach". In José Antonio Ocampo (ed.). Beyond Reforms: Structural Dynamics and Macroeconomic Vulnerability. Stanford University Press, Palo Alto, and Economic Commission for Latin America and the Caribbean, Santiago: 161-188.

Martner, Ricardo, and Varinia Tromben (2003). "Tax Reforms and Fiscal Stabilization in Latin America". In Tax Policy, Public Finance Workshop Proceedings, Banca d'Italia Research Department, Rome: 140-71.

Minsky, Hyman P. (1982). Can "It” Happen Again?: Essays on Instability and Finance. M.E. Sharpe, Armonk, NY.

Nayyar, Deepak (2002). "Capital Controls and the World Financial Authority - What Can We Learn from the Indian Experience?". In John Eatwell and Lance Taylor (eds). International Capital Markets - Systems in Transition. Oxford University Press, New York: 99-126.

Ocampo, José Antonio (2003a). "Capital Account and Counter-Cyclical Prudential Regulation in Developing Countries". In Ricardo Ffrench-Davis and Stephany 
Griffith-Jones (eds). From Capital Surges to Drought: Seeking Stability for Emerging Markets. Palgrave Macmillan, London: 217-44.

Ocampo, José Antonio (2003b). "International Asymmetries and the Design of the International Financial System". In Albert Berry (ed.). Critical Issues in Financial Reform: A View from the South. Transaction Publishers, New Brunswick, NJ: 4574.

Ocampo, José Antonio (2002). "Developing Countries' Anti-Cyclical Policies in a Globalized World". In Amitava Dutt and Jaime Ros (eds). Development Economics and Structuralist Macroeconomics: Essays in Honour of Lance Taylor. Edward Elgar, Aldershot, UK: 374-405.

Ocampo, José Antonio, and Juan Martin (2003). Globalization and Development. Stanford University Press, Palo Alto and Economic Commission for Latin America and the Caribbean, Santiago.

Ocampo, José Antonio, and Gabriel Palma (2004). "Dealing with Volatile External Finances at Source: The Role of Preventive Capital Account Regulations". Processed, Initiative for Policy Dialogue, Columbia University, New York.

Palma, Gabriel (2002). "The Three Routes to Financial Crises: The Need for Capital Controls". In John Eatwell and Lance Taylor (eds). International Capital Markets - Systems in Transition. Oxford University Press, New York: 297-338.

Persaud, Avinash (2000). Sending the Herd off the Cliff Edge: The Disturbing Interaction between Herding and Market-sensitive Risk Management Practices. State Street Bank, London.

Poveda, Raimundo (2000). La Reforma del Sistema de Provisiones de Insolvencia. Banco de España, Madrid.

Prasad, Eswar S., Kenneth Rogoff, Shang-Jin Wei, and M. Ayhan Kose (2003). "Effects of Financial Globalization on Developing Countries: Some Empirical Evidence". IMF Occasional Paper 220, International Monetary Fund, Washington DC.

Rajaraman, Indira (2001). "Management of the Capital Account: A Study of India and Malaysia”. Processed, National Institute of Public Finance and Policy, New Delhi, March.

Reddy, Y.V. (2001). "Operationalising Capital Account Liberalisation: The Indian Experience". Development Policy Review 19 (1), March: 83-99.

Reinhart, Carmen M. and Kenneth Rogoff (2004). "The Modern History of Exchange Rate Arrangements: A Reinterpretation". Quarterly Journal of Economics 119 (1), February: 1-48.

Reisen, Helmut (2003). "Ratings since the Asian Crisis". In Ricardo Ffrench-Davis and Stephany Griffith-Jones (eds). From Capital Surges to Drought: Seeking Stability for Emerging Markets. Palgrave Macmillan, London: 119-138.

Rodrik, Dani, and Andrés Velasco (2000). "Short-Term Capital Flows". In Proceedings of the Annual World Bank Conference on Development Economics 1999. World Bank, Washington, D.C.: 59-90.

Rojas-Suárez, Liliana (2004). "Domestic Financial Regulations in Developing Countries: Can They Effectively Limit the Impact of Capital Account Volatility". Working Paper 01-6, Initiative for Policy Dialogue, Columbia University.

Stiglitz, J. E. (2003). "Whither Reform? Toward a New Agenda for Latin America". CEPAL Review, 80: 7-38. 
Stiglitz, J. E., and Amar Bhattacharya (2000). "The Underpinnings of a Stable and Equitable Global Financial System: From Old Debates to a New Paradigm”. In Proceedings of the Annual World Bank Conference on Development Economics 1999. World Bank, Washington, DC.: 91-130.

Svensson, Lars E. O. (2000). “Open-economy Inflation Targeting”. Journal of International Economics 50: 155-83.

Taylor, Lance (1998). "Capital Market Crises: Liberalisation, Fixed Exchange Rates and Market-Driven Destabilisation". Cambridge Journal of Economics 22 (6), November: 663-76.

United Nations (2003). World Economic and Social Survey 2003. United Nations, New York.

Van Wijnbergen, Sweder (1984). “The Dutch disease: a disease after all?”. Economic Journal 94: 41-55.

Velasco, Andrés (2000). Exchange-Rate Policies for Developing Countries: What Have We Learned? What Do We Still Not Know?. United Nations Conference on Trade and Development (UNCTAD), Geneva, and Center for International Development, Harvard University, Cambridge, MA.

Villar, Leonardo, and Hernán Rincón (2003). "The Colombian Economy in the Nineties: Capital Flows and Foreign Exchange Regimes". In Albert Berry (ed.). Critical Issues in Financial Reform: A View from the South. Transaction Publishers, New Brunswick, NJ: 353-82.

Williamson, John (2000). "Exchange Rate Regimes for Emerging Markets: Reviving the Intermediate Option". Policy Analyses in International Economics 60. Institute for International Economics, Washington, DC. 